\title{
Remarks on the Historiography of Mathematics
}

by

Aldo Brigaglia

University of Palermo

aldo.brigaglia@gmail.com 


\begin{abstract}
In this paper, I examine aspects of the methodological debate that originated in 2010, when the distinguished historian of mathematics Sabetai Unguru reviewed Roshdi Rashed's edition of the Arabic translation of Apollonius' Conics. In his review, Unguru criticized what Rashed calls "l'usage instrumental d'une autre mathématique pour commenter une oeuvre ancienne". I consider this debate very important and will try to place it within in the discussion of the so-called "geometric algebra" that goes back to the seventies, by tracing the contributions of the main figures who took part in it.
\end{abstract}
About the Author
ALDO BRIGAGLIA, now retired, is a former full professor of "Matematiche Complementari" in the mathematical department of the University of Palermo. His principal research interests are in the history of mathematics and, above all, in the history of Italian algebraic geometry. His recent papers include: "Historical Notes on Star Geometry in Mathematics" (with N. Pal- ladino and M. Vaccaro) in M. Emmer and M. Abate edd. Imagine Math6 (Springer, 2018); "Es steht alles schon bei Dedekind. Aspetti dell' influenza dell' opera di Dedekind sulla matematica italiana" in Matematica, Cultura e Società. Rivista dell' Unione Matematica Italiana (2017); and "Picard and Italian Mathematicians" in F. Brechenmacher, G. Jouvet, L. Mazliak, and R. Tazzioli edd. Italian Mathematics in France 1815-1928 (Springer, 2016). 
he discussion that I will address in these pages was prompted
by the methodological decisions taken by Roshdi Rashed in his
memorable edition, translation, and commentary on the Arabic/ Islamic mathematical tradition. I will concentrate on this discussion after I have placed it in a larger context that goes back to a distant past. Since I believe that this discussion is of great relevance for historians of mathematics (and more generally for cultural historians), I will limit my personal opinions to a minimum. Instead, I will try to do justice to all the points of view expressed in this discussion.

The discussion was prompted by Sabetai Unguru and his review [2010] of Rashed's Apollonius de Perge. Coniques. Tome 2.2. Livre IV: Commentaire historique et matématique [2009]. Rashed stated his historiographical point very clearly in the first volume of his editorial project. I report some of the excerpts quoted by Unguru. They will give a first idea of the nature of this discussion:

(1) Le recours aux termes de la géométrie algébrique risque de déplaire. ...Il s'agit bien d'une théorie géométrique des sections coniques: point de géométrie algébrique, point de géométrie différentielle. Et pourtant, nous avons pris la liberté de recourir dans nos commentaires à la géométrie algébrique, encourant ainsi, en toute connaissance de cause, un reproche d'anachronisme de la part des gardiens du temple. [Unguru 2010,34]

(2) Il s'agit plutôt, nous semble-t-il, de l'effet du choix délibéré d'un style d'écriture de l'histoire, par élucidation rétrograde, telle que le pratiquait Bourbaki: partir du présent pour restituer le passé; et aussi d'un souci didactique: s'adresser aux contemporaines dans la langue de leurs mathématique. [Unguru 2010, lvi]

(3) Pour lire une œuvre mathématique ancienne, il nous a donc semblé nécessaire de solliciter l'aide d'une autre mathématique, à laquelle on emprunte les instruments qui pourront en restituer l'essence. Un modèle construit dans une autre langue mathématique permet d'aller plus loin dans l'intelligence du texte, particulièrement lorsque cette langue est celle d'une mathématique plus puissante, mais qui trouve dans l'œuvre commentée l'une des sous sources historiques. 
Pour les Coniques, c'est la géométrie algébrique élémentaire qui fournit ce modèle. [Unguru 2010, 35]

(4) Dans le cas des Coniques, on observe, à partir du IXe siècle, une extension de certaines de leurs chapitres, ainsi que leur application aux domaines les plus divers et leur contribution, essentielle, à la création de la géométrie algébrique élémentaire. Il suffit pour s'en convaincre de lire l'Algèbre d'al-Khayyām, les Équations de Sharaf al-Din al-Tūsi, la Géométrie de Descartes, la Dissertation Tripartite de Fermat. Négliger le contexte des successeurs conduit inévitablement à tronquer l'histoire de l'œuvre. Même s'ils transforment son sens, les successeurs permettent en effet à l'historien de voir l'œuvre avec d'avantage de clarté et de profondeur. Cette préoccupation a été la nôtre ailleurs. [Unguru 2010, 36]

The excerpts above may give the impression that Rashed shares the approach of the so-called geometric algebra promoted by Heath and Zeuthen. This is also suggested by Unguru, who says, "This is how Heath and Zeuthen proceeded when appealing to geometric algebra" [Unguru 2010, 34]. It is, therefore, useful to make a brief excursus and recall another, older debate, revived in the 1970s, in which Unguru himself took part.

The label "geometric algebra" has been defined as the attempt to interpret part of Greek mathematics, typified by book 2 of Euclid's Elements, as a translation of Babylonian algebraic identities and procedures into geometric language [Berggren 1984]. In reality, geometric algebra is based on a much older tradition. Some of the first protagonists of the birth of analytic geometry used algebraic methods in geometry (e.g., Viète, Descartes, and Newton, among others). They thought that books 2 and 6 of Euclid's Elements were actually the translation in geometrical fashion of pre-existing algebraic theorems. In particular, Newton, in the appendix to his Arithmetica universalis, says "geometria excogitata fuit ut expedito linearum ductu effugeremus computandi tedium". In other words, contrary to the views of some of his contemporaries, Newton held that geometry was not merely a kind of coating on algebraical calculus but rather an achievement destined to overcome the calculating complexity of algebra and arithmetic.

Of course, these were not historiographical considerations; rather, they reflected the attempt of the creators of a new mathematical language to make contact with the language (and, indeed, the results) of those who had preceded them. The introduction of this way of thinking into the historiographical tradition is usually attributed to the Danish mathematician 
Hieronimus Zeuthen in the second half of the 19th century, after the discovery of Egyptian and especially Babylonian mathematical materials by Otto Neugebauer and Barthel Van der Waerden. With the work of these two eminent mathematicians, the theory of "geometric algebra", adopted by various historians of mathematics (including Heath and Boyer), was established.

It should be stressed, however, that this was a precise historiographical thesis. As such, it was not meant to be a methodological proposal, even though it was based on specific methodological choices, which were nevertheless different among the various proponents of this thesis. It became a thesis about the method to be used in historical research after the publication of the seminal article by Unguru, "On the Need to Rewrite the History of Greek Mathematics", first published in Archive for the History of Exact Science in $1975 .{ }^{1}$ After describing in critical terms the theory of geometric algebra, Unguru tries to identify the cause that has led to what he characterizes as a scandalous situation. He writes:

It is in truth deplorable and sad when a student of ancient or medieval culture and ideas must familiarize himself first with the notions and operations of modern mathematics in order to grasp the meaning and intent of modern commentators dealing with ancient and medieval mathematical texts. With very few and notable exceptions, Whig history is history in the domain of the history of mathematics; indeed, it is still, largely speaking, the standard, acceptable, respectable, "normal" kind of history, continuing to appear in professional journals and scholarly monographs. It is the way to write the history of mathematics. And since this is the case, one is faced with the awkward predicament of having to learn the language, techniques, and way of expression of the modern mathematician...if one is interested in the historical exegesis of premodern mathematics; for it is a fact that the representative audience of the mathematician fathering "historical" studies consists of historians...rather than mathematicians....As to the goal of these so-called "historical" studies, it can easily be stated in one sentence: to show how past mathematicians hid their modern ideas and procedures under the ungainly, gauche, and embarrassing cloak of antiquated and out-of-fashion ways of expression; in other words, the purpose of the historian of mathematics is to unravel and disentangle past mathematical texts and transcribe them into the modern language of mathematics, making them easily available to all those interested. [Unguru 2004, 386]

${ }^{1}$ This article and others that followed in the ensuing debate are now collected in Unguru 2004. 
The rest of this article is a critique of the thesis of geometric algebra, in which the perceived errors of this approach are linked to what is regarded as a mistaken methodological conception of the history of mathematics.

Especially offensive to historians who had been (or were still) first-class mathematicians, but who had dared to venture into the field of history, was the use of sociological or biographical considerations. Unguru writes:

Let me only suggest again...that the fact that the history of mathematics has been typically written by mathematicians might have something to do with it...they were mathematicians who have either reached retirement age and ceased to be productive in their own specialities or became otherwise professionally sterile. However, both of these categories had something in common: in order to serve humanity and expend untapped remnants of scholarly energy, they decided to employ their creativity in a field, history of mathematics, "half" of which - the history — was too alien and exotic while the other "half" - the mathematics-was, alas, too familiar to them; the underlying assumption being that history does not really require any training, its narrative, reportorial methods and techniques being common-sensical and self-evident; and since they were highly proficient in mathematics they had all which was required to become successful historians of mathematics!...the reader may judge for himself how wise it is for a professional to start writing the history of his discipline, when his only calling lies in professional senility which bars him from encroaching on more friendly, familiar and hospitable territory! [Unguru 2004, 405]

The reader will forgive me for these long quotations, but it seems to me essential to establish the frame of reference in which to insert Unguru's harsh criticism of the methodology adopted by Rashed in his commentary on the Arabic versions of Apollonius' text.

The controversy raised by the Israeli historian provoked both more or less violent replies and a rich debate that lasts until today. Firm responses came from mathematicians targeted (and, indeed, offended) by Unguru's words; among them, I mention Van der Waerden, Hans Freudenthal, and André Weil. ${ }^{2}$ Their replies prompted a debate that lasted until 1979, when Unguru himself replied with an intervention that was unfortunately rejected by the Archive. It is not my task to give a full account of this important debate, which touched upon historiographical problems (the consistency of the hypothesis

2 The replies by Van der Waerden and Weil, as well as the response by Unguru, are collected in Christianidis 2004. Freudenthal's reply is reprinted in Freudenthal 1977. Another important contribution to this debate is by Weil in his speech offered at the plenary session of the International Congress of Mathematics held in Helsinki in 1978 [Weil 1980]. 
of "geometric algebra"), more general themes (the very definition of the concept of algebra), and properly methodological questions (the legitimacy of a modern reading of classical texts and its usefulness toward their interpretation). I limit myself to offering a quotation from Weil 1980 because it characterizes well the methodological questions at stake:

How much mathematical knowledge should one possess in order to deal with mathematical history? According to some little more is required than what was [ed. needed] to [ed. understand] the authors one plans to read about; some go so far as to say that the less one knows, the better one is prepared to read those authors with an open mind and avoid anachronisms. Actually, the opposite is true. An understanding in depth of the mathematics of any given period is hardly ever to be achieved without knowledge extending far beyond its ostensible subject-matter. More often than not, what makes it interesting is precisely the early occurrence of concept and methods destined to emerge only later into the conscious mind of mathematicians; the historian's task is to disengage and trace their influence or lack of influence on subsequent developments. [Weil 1980, 231]

Weil rejects the charge of anachronism:

[A]nachronism consists in attributing to an author such conscious knowledge as he never possessed; there is a vast difference between recognizing Archimedes as a forerunner of integral and differential calculus, whose influence on the founders of calculus can hardly be overestimated, and fancying to see in him, as has sometimes been done, an early practitioner of calculus. [Weil 1980, 232]

In the four decades since 1979, virtually no text on the methodological issues related to the study of ancient mathematics (Egyptian, Babylonian, Greek, and Arabic) has failed to refer to the debate reconstructed here. For the sake of the interested reader, I compiled a list (albeit incomplete) of some works that refer to this debate [see p. 22obelow]. In the most recent ones, the reader will find additional bibliographical information. Here, I am content to recall two points that have emerged.

David Rowe writes that "Alexander Jones told me that Unguru's position could now be regarded as the accepted orthodoxy" («le gardien du temple» mentioned by Rashed) [Rowe 2012, 37]. Evidently, according to many scholars, the position defended by Unguru has gained ground and is consolidated to the point of being perceived as a sort of orthodoxy. Jens Høyrup makes the following remark:

As analysis of the writings of the actors involved shows, these have rarely read each other's works with much care. That already holds for many of those who have claimed inspiration from Zeuthen, but those who have criticized the idea 
have felt even less obliged to show that they knew what they spoke about. [Høyrup 2016, Abstract]

This dispirited assessment shows that the debate is far from over.

Such is the context for Unguru's critical review of the commentary by Rashed on book 4 of Apollonius' Conics. I believe that this context helps us to understand why the excerpts from Rashed were deemed inadmissible by Unguru. It is time now to turn to Unguru's objections.

With respect to excerpts 1 and 2 on page 207 , Unguru recalls the main lines of his criticism of geometric algebra:

This is how Heath and Zeuthen proceeded when appealing to geometric algebra in their elucidation of the Conics and this is also the "historical" methodology of Bourbaki.... Still, Rashed's reasons for calling on "algebraic geometry" (sic!) as his main historical interpretative tool are different, one being instrumental and the other historiographic. [Unguru 2010, 34]

It is worth recalling that, in his avant-propos to the first volume of his edition of the Conics, Rashed had distanced himself from the interpretations linked to the hypothesis of geometrical algebra:

Th. Heath n'a pas hésité à lire les Coniques à la lumière de la géométrie algébrique. Plus encore, il a justifiè cette lecture par la fameuse doctrine de "l'algèbre géométrique des Grecs", déjà défendue par Zeuthen et Tannery, et selon nous historiquement insoutenable. [Rashed 2009, viii]

Furthermore,

Dire que les Coniques sont un livre de géométrie, c'est enfoncer une porte ouverte. Il suffit de jeter un coup d'œil sur ce traité pour y constater l'absence de tout équation d'un courbe plan et, d'ailleurs, du moindre concept algébrique. On vérifiera, par exemple...que le concept central de symptoma n'est nullement équivalent à celui d'équation. [Rashed 2009, vii]

Unguru has clarified this. He also makes the following remark in a footnote: "Surprisingly, and inconsistently, it seems to me, Rashed rejects the legitimacy of geometric algebra". This is an odd remark. Here I am content to recall Høyrup's point that "as soon as Unguru sees the word "algebra" [and I would add "geometric algebra"] he stops reading the explanations of the writer" [Høyrup 2016, 32]. What appears to be a contradiction has been clarified by Ivo Schneider:

[I]t is, for example, necessary to distinguish whether an author represents the contents of a Greek mathematical text in algebraic dress while referring to the underlying geometrical argumentation of the original, or he claims the algebraic representation to correspond to the proper thought of the Greeks. [Schneider 2016, vii: trans. Høyrup 2016, 8] 
This is exactly what is at stake, in my view. While Rashed presents Apollonius' text in a geometric argumentation, he does not ever derive the consequence that this (or something similar to this) is the "true" intention of the Greek mathematician and that he, too, dressed his algebraic reasoning in a geometric argumentation. Rashed himself makes this very clear when he speaks of his "instrumental" use of geometry:

Bref, si l'usage instrumental d'une autre mathématique pour commenter une œuvre ancienne nous a semblé indispensable, c'est surtout en raison de ce rapport diffus d'identité et de différence qui les unit l'une à l'autre. Que l'instrument, le modèle, ne soient pas l'objet, c'est un truisme. Ils ne relèvent pas de la même Mathesis. [Rashed 2009, ix]

It is here, in my view, that we see the main reason behind Unguru's harsh criticism. Unguru thinks that this position is conceptually self-contradictory. It is an attempt, as it were, "to eat the cake and keep it too". Here Unguru's obsession with geometric algebra resurfaces:

And, by the way, what exactly is, for Rashed, the difference between "geometrical algebra", which he rejects and, "algebraic geometry", which he embraces, though, at times...he seems to conflate and confuse them? [Unguru 2010, 38]

It seems to me that there are two issues that must be kept separate (according to what Schneider also indicates):

(1) the historiographical hypothesis that attributes modern methods and ideas to authors of another era-methods and ideas that are different only in some linguistic aspects from our own;

(2) the practice of translation into modern language of the mathematics of another epoch which only serves to help us better understand the mathematical contents expressed with notions very different from ours. It is not at all true that the latter implies the former, or that it is contradictory to use the latter while rejecting the former. In other words, one can discuss the usefulness of a translation but certainly not its legitimacy.

Let us quote, one more time, from the recent article by Høyrup: "[L]ater (well after 2001, perhaps in 2011) he [Unguru] told me that even he had to start with symbolic algebra in order to grasp Apollonius" [Høyrup 2016, 32]. This is exactly the need which Rashed has tried to address. While it is more than legitimate to discuss the method chosen by Rashed, I do not think that it is useful to attribute to him aims and ideas different from those he has in fact expressed. Unguru makes an analogous, and even harsher, criticism with respect to excerpts 3 and 4 on page 208 above. He describes them as an "unbelievable statement” [Unguru 2010, 35]. 
There is another point concerning what is perhaps the most significant statement made by Rashed, that is, the statement that the reference translation used for the first four books of the Conics, namely, that by ibn al-Haytham, is more reliable than the original redaction of Apollonius, the one preserved in Greek by Eutocius, to which reference had so far been made. On this point, Unguru is more open to dialogue, although with reservations:

His text differs from the Eutocian Greek text in both trivial and substantive matters.... With the publication of this book, any student of book 4 of the Conics had at his disposal a welcome and necessary addition to the preserved Greek text, ultimately stemming from another, and better, manuscript tradition than that available to Eutocius. Sadly, this is served in the framework of an unacceptable historical approach. [Unguru 2010, 36]

We thus get a summary of Unguru's assessment of what Rashed has done. Almost at the same time as Unguru, Nathan Sidoli expressed a much harsher criticism on this very issue: "His [Rashed's] procedure for this is quite incredible" [Sidoli 2011, 539]. Sidoli's review concentrates on this issue but is largely favorable. It is worth noting, however, that there is no trace in this review of the methodological issues that are so important to Unguru.

In subsequent years, two other reviews were published in Aestimatio (old series) on the edition and translation of classical works of Arabic mathematics by Rashed (in one case, written in collaboration with Hélène Bellosta). The first was by Clemency Montelle [2011] and the second, by Jeffrey Oaks [2014]. Both reviews take a critical stance with respect to the methodology used in the commentaries. This stance is similar to that of Unguru, but is much less "ideological". In fact, Montelle is cautious. Speaking of the careful study done by Rashed and Bellosta of the second-degree equation that algebraically translates the problem studied by Apollonius, she writes:

Being careful to caution that this approach is worlds apart from the original conception, the algebraic orientation allows them, they maintain, to explore the structure of the work and investigate the systematic character and completeness of the approach of Apollonius. But while one can appreciate, with some effort, the intricacy of this work and its mathematical scope, such an orientation does not directly address the original issues the authors raised at the outset, such as motivation, exposition, and approach in the Greek geometrical context. [Montelle 2011, 184] 
Later on, she adds:

The parallel processes of analysis and synthesis, the very organizing feature of Apollonius's treatment of each configuration become muted as a result of this algebraic transformation. The documentation of investigation of the details and nuances of these processes in this context remains then for future scholarship. [Montelle 2011, 185]

Since I do not believe that Rashed and Bellosta thought that the aim of the algebraic translation was to give answers to the actual use of the methods of geometrical analysis by Apollonius, Montelle's review can be situated in the debate on the methodology used by the authors.

Another interesting observation, partly taken up by Oaks, concerns the lack of interest on the part of Rashed and Bellosta in engaging with the rest of the scientific community on the topics discussed in the book: "One notable absence in this publication is an engagement with the contemporary scholarly community" [Montelle 2011, 186]. This is an interesting observation, the discussion of which goes beyond the scope of this review.

Oaks' lengthy review takes up Unguru's theme of the perceived anachronism of the reconstructions offered in a modern language. He writes:

We are used to this from Rashed. He has exhibited a string of publications in which he gives a modern reading of premodern mathematics, always careful in a preface to give a brief warning that the modern models are anachronistic. Yet, in practice, he treats them as if they are equivalent to the originals. [Oaks 2014, 43]

In support of this, Oaks cites the book reviews by Unguru and Montelle.

The belief that the modern reading of ancient texts is the origin of all evils, and that any other interpretation springs from this "original sin", appears to be central to this whole discussion. Of course, Oaks knows and cites Rashed's position on the subject; but, it seems to me, he believes that such warnings are purely a façade. (It will be remembered that Unguru, in this regard, believes that Rashed's theory and practice are contradictory.) It is crucial, therefore, to understand what exactly Rashed means by "instrumental". I will come back to this in my conclusion.

At any rate, Oaks deals with other issues that seem to me more substantial and deserving of a more in-depth discussion. I will mention some of them. To begin, Oaks expresses a position radically different from that of Rashed about the essence of Arabic medieval algebra. For Oaks,

Medieval Arabic algebra was part of arithmetic. As a technic for solving numerical problems, it was practised alongside methods like a single and double false position, working backwards, and analysis. In these methods, one calculates 
directly with the numbers given in a problem to get the answer. What distinguishes a solution by algebra...is that an unknown number is named and an equation is set up and then solved. [Oaks 2014, 27]

It follows as a criticism that Rashed would be "turning arithmetic into algebra" [Oaks 2014, 33]. Instead, Rashed's position consists in underlining the elements of discontinuity between the arithmetic and the algebraic tradition inaugurated by al-Khwārizmi and developed by Abū Kāmil, which he finds in the very collocation of the study of the six canonical equations. ${ }^{3}$ It is a classificatory study that precedes the resolution of individual problems and is logically independent from them. To put it in Rashed's words:

Ce n'est pas lors de la résolution des problèmes qu'al-Khwārizmi trouve ces équations: la classification précède en effet toute problème. Celle-ci est résolument introduit comme première étape obligé de la construction d'une théorie des équations des deux premiers degrés, destinée à devenir le cœur d'une discipline mathématique. [Rashed 2007, 24]

Of course, this does not preclude that al-Khwārizmi was influenced by his predecessors:

Cette démarche, à l'évidence inspirée par ses prédécesseurs et contemporaines dans d'autres disciplines, est doublement irréductible à ce qu'on peut rencontrer dans d'autres traditions: babylonienne, diophantienne, héronienne, celle d'Aryabhāta, ou celle de Brahmagupta. [Rashed 2007, 24]

Once the purely verbal problems are removed, this debate appears to be of great interest. In connection with this debate, I find Oaks' remark odd. While the invented algebraic versions are criticized (with regard to the solution of the equation $x^{2}+10 x=39$ in notes $10,12,17$, and 23 ), he claims that in notes $9,11,13$, and 18 we are given "purely arithmetical and, thus, more appropriate explanations for Abū Kāmil's procedures for finding the $m \bar{a} l$ $\left(x^{2}\right)$ directly". Perhaps an in-depth discussion of this apparent contradiction would have allowed a better understanding of their respective points of view. However, it seems to me that the difference between the two ways of treating the question goes back to the same Abū Kāmil who used al-Khwārizmi's

3 The six equations are (in Rashed's translation of al-Khwārizmi):

[D] es carrés sont égaux à des racines $\left(a x^{2}=b x\right)$; des carrés sont égaux à un nombre $\left(a x^{2}=b\right)$; des racines sont égaux à un nombre $(a x=b)$; des carrés plus des racines son égaux à un nombre $\left(a x^{2}+b x=c\right)$; des carrés plus un nombre sont égaux à des racines $\left(a x^{2}+b=c x\right)$; des racines plus un nombre sont égaux à des carrés $\left(a x+b=c x^{2}\right)$. [Rashed 2007, 98, 100] 
resolutive formula to derive the root, and his own formula to derive the square $(m \bar{a} l)$.

If the equation is given as $x^{2}+a x=b$, his formula gives

$$
x^{2}=\frac{a^{2}}{2}+b-\sqrt{a^{2} b+\left(\frac{a^{2}}{2}\right)^{2}} \text {. [Rashed 2012, 152] }
$$

This result is demonstrated by means of geometry. The algebraic translation of the first formula is direct and corresponds, as already mentioned, to what was presented by al-Khwārizmi. Rashed presents it through the geometrical steps of Abū Kāmil translated into algebraic notation. A second demonstration is more arithmetical. Rashed presents it only in its final form. Personally, I think that the meaning and the different demonstrations given by Abu Kāmil of the two equivalent formulas could have given rise to a much more interesting discussion than the polemics on the use of an algebraic/symbolic translation.

Another point of disagreement has to do with Rashed's statement that

c'est dans ce livre [le troisième de l'algèbre de Abū Kāmil] en effet que l'on rencontre la première étude délibérément et entièrement consacrée à la l'analyse indéterminée rationnelle [Rashed 2012, 145].

This statement concerns a controversy of considerable historical importance-namely, the relations between the Arabic algebra and the work of Diophantus. This controversy is resumed, and somehow extended, in a subsequent review. Oaks writes:

Diophantine analysis, according to Rashed, does not originate with Diophantus. This is a consequence of Rashed's claim that algebra was invented by alKhwārizmi as a science of equations in the early ninth century. Since algebra is necessary for Diophantine analysis, Diophantus could not have practiced either one. [Oaks 2015, 105]

Oaks concludes his analysis as follows:

Rashed denies indeterminate analysis to Diophantus by emphasizing superficial differences with Abū Kāmil, and by distorting the premodern arithmetic and algebra by rewriting everything with modern algebraic symbols. Then, by interpreting Abū Kāmil's text through these symbols, he invokes a grossly anachronistic interpretation of the solutions in terms of modern projective geometry. [Oaks 2015, 105]

So, again, the root of all misinterpretations would be in the translation of pre-modern texts into modern symbolism.

I will not elaborate on this issue and will not expand on Oaks' criticism [2015] of Rashed's interpretation of the work by Viète, which goes beyond the scope of these remarks. 
The final point of Oaks' harsh criticism concerns the translation (in the commentary) of the indeterminate problems of Abū Kāmil in terms of algebraic geometry. In this case, the criticisms are similar to those of Unguru. As said before, I believe that to understand (even without possibly sharing) Rashed's position, it is necessary to read his definition of the concept of instrumental reading carefully. I will return to this in the light of what is offered in Rashed 2012.

Rashed relies on the following assumption: even if a philologically rigorous reconstruction is indispensable, the idea that it is possible to interpret an author who lived several centuries ago relying exclusively on this philological rigor is illusory:

Rédigés il y a plus de onze siècles, ces traités le furent dans un contexte totalement étranger au nôtre, que nous ne connaissons pas et qui ne nous est que partiellement accessible. La tentation la plus immédiate, à laquelle certains n'ont pas résisté, est d'interpréter Abū Kāmil à l'aide de ses propre mots. Illusion d'un apprenti-philologue. [Rashed 2012, ix]

Instead, Rashed proposes an alternative approach in which ample use of mathematical models that are based on modern language is made:

Il s'agit...de combiner une analyse philologique sûre, une histoire de l'élaboration du texte et des pratiques et procédés mis en œuvre par son auteur pour le rédiger, et, enfin, des modèles mathématiques construit à partir des disciplines que ce texte a contribué à fonder et, donc, appartenant à des mathématiques postérieures à celui-ci, modèles aptes à révéler la mathesis de l’auteur. [Rashed 2012, $\mathrm{x}$ ]

This must go hand in hand with the utmost care not to confuse the model with the original text:

Mais le recours à ces modèles n'est que instrumental: indispensable, en raison de ce rapport diffus d'identité et de différence que relie les contextes, l'algèbre de Abū Kāmil aux disciplines modernes, l'instrument ne se substitue pas à l'objet, cela va de soi. Il relève d'une tout autre mathesis. L'historien doit donc le manier avec prudence et sagacité, pour ne pas attribuer au texte ancien les notions véhiculées par l'instrument : le modèle. [Rashed 2012, ix-x]

In conclusion, I can say that it is unavoidably necessary for any historian-at least, it seems so to me-to read an ancient text first by translating it into modern terms so as to grasp its profound mathematical meaning, and only then to look for the thread that, in the given historical circumstances, the author could have followed concretely. This makes understanding of the ancient text easier for the modern reader, even if not a specialist ("adding a mathematical commentary; this will allow the modern reader to follow more easily, without problems in language or overlong descriptions" [Rashed 2013b, 34]). At the same time, it enables the reader-thanks to the commentary, the sole goal of which is "mettre en lumière le visée de la recherche 
géométrique menée par Apollonius" or the other relevant authors to plumb "la profondeur de ses concepts et de ses résultats et en apprécier la richesse, per cui il nous a fallu...emprunter d'autre modèles mathématiques inventés plus tard" [Rashed 2009, v].

With reference to the Conics, Rashed claims that

les objets géométriques étudiés dans les Coniques possèdent bien ces propriétés, qui ne seront appréhendées et révélées que par les successeurs d'Apollonius, depuis Desargues. C'est donc en restant fidèle à la pensée du mathématicien alexandrin que l'historien peut s'inspirer de ces propriétés, pour mieux pénétrer cette réalité mathématique que celui-ci abordait les moyens de la géométrie de son temps. [Rashed 2009, 78]

This is a historiographical picture that places historical research in direct relation to the past both with respect to the work studied (the past that has supplied to the author "les moyens de la géométrie de son temps") and with the potential developments contained implicitly in the work and which can be explicated in a dialectical relationship with the creation of new means of analysis.

Thus, in my opinion, the algebraic reading made by the 17 th-century mathematicians (Viète and Descartes, among others) of the second book of Euclid's Elements, even if it led to controversial and partly unacceptable historiographical hypotheses, has certainly thrown a new and clearer light on the Elements and provided a new key to reading them. Without the new methods of Monge and Poncelet, it would have been impossible for historians to frame the works of Desargues, Pascal, or La Hire correctly. Therefore, the work of mathematicians and that of historians of mathematics appears to be in close relationship, without blurring their respective specificities.

The debate on these issues would have been extremely fruitful had it not been vitiated by purely ideological prejudices. I would like to conclude by quoting the opinion of a friend and colleague who summarizes the question very well:

It is necessary, in my opinion...to explain things in a more modern language, for two reasons: first because the use of a more refined language highlights merits and defects of the original view; this places the original view in a more exact scientific and historical perspective and, ultimately, makes us better understand what the authors at the time were trying to do; second because if this is not done, the original view remains incomprehensible to the vast majority of today's mathematicians, which is contrary to what is said that should be done, namely, to bring the two communities of historians of mathematics and professional mathematicians together. ${ }^{4}$

4 C. Ciliberto, personal communication, 13 Aug 2017. 


\section{APPENDIX}

I list a few works on the debate about "geometric algebra", with a special concentration on the last 15 years. This incomplete list is organized chronologically. Where bibliographical information is missing, it can be found in the Bibliography which follows.

\section{J. L. Berggren 1984.}

W. R. Knorr. 1990. "Nouvelles approches des mathématiques. Sources, problèmes et publications". Impact 159: 237-251.

D. Rowe. 1996. "New Trends and Old Images in the History of Mathematics”. Pp. 3-16 in R. Calinger ed. Vita Mathematica. Washington, DC.

M. Galuzzi. 2002. trans. "Premessa". Pp. i-vii in A. Weil. Storia della matematica: come e perché e come. Milan.

R. Netz. 2004. Problems to Equations. Cambridge, UK.

S. Unguru 2004.

N. Sidoli. 2006. Review of Christianidis 2004. Historia Mathematica 33: $491-493$.

D. Rowe 2012.

L. Corry. 2013. "Geometry and Arithmetic in the Medieval Traditions of Euclid's Elements: A View from Book II". Archive for the History of Exact Science 67: 637-705.

N. Sidoli and G. Van Brummelen. 2014. From Alexandria, through Baghdad. New York.

V. Blắsjö. 2016. "In Defence of Geometric Algebra”. Archive for the History of Exact Science 70: 25-359.

M. Sialaros and J. Christianidis. 2016. "Situating the Debate on 'Geometrical Algebra' within the Framework of Premodern Algebra”. Science in Context 29: 129-150.

I. Schneider 2016.

J. Høyrup 2016. 


\section{BIBLIOGRAPHY}

Berggren, J. L. 1984. "History of Greek Mathematics: A Survey of Recent Research”. Historia Mathematica 11:394-410.

Christianidis, J. 2004. ed. Classics in the History of Greek Mathematics. New York.

Freudenthal, H. 1977. "What Is Algebra and What Has It Been in History". Archive for the History of Exact Science 15:189-200.

Høyrup, J. 2016. "What Is 'Geometric Algebra', and What Has It Been in Historiography?” Preprint 15 January 2016. http://akira.ruc.dk/ jensh/ Publications/2016_What\%20is\%2o'Geometric\%2oAlgebra'_S.pdf. In print: AIMS Mathematics 2 (2019) 128-160. Citations are from the preprint.

Montelle, C. 2011. Review of Rashed and Bellosta 2010. Aestimatio os 8: $183-187$.

Oaks, J. 2014. Review of Rashed 2009. Aestimatio os 11:24-49. 2015. Review of Rashed 2012. Aestimatio os 12: 105-109.

Rashed, R. 2007. Al-Khwārizmi. Le commencement de l'algèbre. Paris. 2008. Apollonius de Perge. Coniques. Tome 1.1: Livre I texte grec et arabe établi, traduit et commenté. Berlin

2009. Apollonius de Perge. Coniques. Tome 2.2. Livre IV: Commentaire historique et matématique. Berlin.

2012. Abū Kāmil. Algèbre et analyse diophantienne. Berlin. 2013a. Histoire de l'analyse diophantienne classique. D’Abū Kāmil à Fermat. Berlin.

_2013b. Ibn al-Haytham and Analytical Mathematics. Translated by S. Glynn and R. Wareham. Abingdon, UK/New York. Translation of the French edition of 1993.

Rashed, R. and H. Bellosta. 2010. Apollonius de Perge. La section des droits selon des rapports. Berlin.

Rowe, D. 2012. "Otto Neugebauer and Richard Courant: On Exporting the Göttingen Approach to the History of Mathematics". Mathematical Intelligencer 34: 29-37.

Sidoli, N. 2011. "Apollonius' Conics: The Greek and Arabic Traditions". ISIS 102: 537-542.

Schneider, I. 2016. Archimedes. New York. 
Unguru, S. 1975. "On the Need to Rewrite the History of Greek Mathematics". Archive for the History of Exact Science 15: 67-114.

- 2004. "Methodological Issues in the Historiography of Greek Mathematics". See Christianidis 2004, 383-461. 2010. Review of Rashed 2009. Aestimatio os 7: 29-42.

Weil, A. 1980. "The History of Mathematics: Why and How". Proceedings of the International Congress of Mathematics, Helsinki 1978. Academia Scientiarum Finnica 1: 227-236. 